\title{
Analysis of psychological factors and sexual life in postmenopausal women: A cross-sec- tional study
}

\author{
Postmenopozal dönemdeki kadınlarda psikolojik belirtiler ve cinsel \\ yaşamın incelenmesi: Kesitsel çalışma

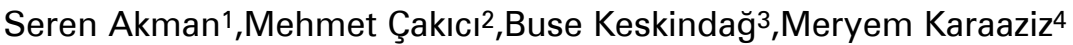 \\ ${ }^{1}$ Psych, ${ }^{2}$ Prof., ${ }^{4}$ Assis. Prof., Department of Psychology, Near East University, Nicosia, TRNC https://orcid.org/0000-0002-0085-612X \\ ${ }^{3}$ Psych. Department of Psychology, European University of Lefke, TRNC.
}

\section{SUMMARY}

Objective: The aim of this study was to analyze the psychological and sexual experiences of postmenopausal women. Method: This cross-sectional study included 100 females (50 postmenopausal and 50 nonmenopausal women). The symptoms of menopause were assessed by the Menopausal Symptoms Scale (MRS), psychological symptoms were assessed by the Symptoms Check List (SCL-R 90), and sexual functions were evaluated by the Arizona Sexual Experience Scale (ASEX) and the Golombok Rust Inventory of Sexual Satisfaction (GRISS). Results: The findings indicated that mean scores of all subscales of the SCL-R 90 were significantly higher among postmenopausal women in comparison with non-menopausal women. No significant differences were found between postmenopausal and non-menopausal women in terms of sexual satisfaction. However, mean scores of vaginusmus and anorgasmia subscales of the GRISS were significantly higher in postmenopausal women than non-menopausal women. Discussion: This study showed that menopause may affect women's mental health because of its psychological consequences. Although menopause can influence sexuality because of physical consequences, findings indicated that menopausal women tend to report they still have sexual satisfaction. Multidimensional health care including psychological support could be efficient for menopausal women.

Key Words: Menopause, sexual function, psychological factors

(Turkish J Clinical Psychiatry 2019;22:27-35)

DOI: $10.5505 / \mathrm{kpd} .2018 .58070$

\section{ÖZET}

Amaç: Bu çalışma, postmenopozal dönemdeki kadınlarda psikolojik belirtiler ve cinsel yaşamın incelenmesini amaçlamaktadır. Yöntem: Bu kesitsel çalışmaya, 50 postmenopozal, 50 menopoza henüz girmemiş 100 kadın katılmıştır. Katılımcıların menopoz semptomlarını belirlemek amacıyla Menopoz Semptomları Değerlendirme Ölçeği, menopozun psikolojik etkilerini belirlemek amacıyla Belirti Tarama Testi, menopozun cinsel hayata etkisini değerlendirmek amacıyla ise Arizona Cinsel Yaşantılar Ölçeği ve Golombok-Rust Cinsel Doyum Ölçeği kullanılmıştır. Bulgular: Calışma bulguları, menopoza girmiş kadınların SCL-R 90'ın tüm alt ölçeklerinden menopoza girmemiş kadınlara göre daha yüksek puan aldıklarına işaret etmektedir. Fakat, menopoza girmiş olan kadınlar ile menopoza henüz girmemiş kadınlar arasında cinsel doyum açısından anlamlı bir fark bulunmamıştır. Buna rağmen, GRISS alt ölçekleri olan vajinismus ve anorgazmi incelendiğinde, menopoza giren kadınların, henüze menopoza girmemiş kadınlara göre anlamlı olarak daha fazla puan aldıkları tespit edilmiştir. Sonuç: Bu çalışma, kadınların ruh sağlıklarının menopozun getirdiği psikolojik etkenler tarafından etkilenebileceğini göstermiştir. Getirdiği fiziksel sonuçlar yüzünden menopoz cinselliği etkilese de bulgular, menopoza girmiş olan kadınların cinsel doyum rapor ettiğine işaret etmektedir. Psikolojik desteği de içeren çok boyutlu sağlık hizmetlerinin, kadınlara menopoza girdikleri süreçte yardımcı olabileceği düşünülmektedir.

Anahtar Sözcükler: Menopoz, cinsel işlevsellik, psikolojik etkenler 


\section{INTRODUCTION}

Menopause is one of women's natural and normal life stages. The World Health Organization (WHO) defines menopause as "permanent termination of menstruation as a result of the loss of ovarian activity" (1). Women who are 45-55 years old usually experience menopause (2). Menopause can occur in three different phases; early, natural and surgical stage. Early menopause occurs below the age of 40 years, which can be defined as "premature menopause" or "premature ovarian failure" (3). The other type of menopause is natural menopause, which is related with the exhaustion in physiological conditions (4). On the other hand, surgical menopause includes operations that involve the removal of ovaries (5). Some researchers have identified problems related to menopause in the context of biopsychosocial perspective $(6,7)$.

Due to biological changes on the body, women who are in the menopausal period can show several physical symptoms including feeling hot, night sweats, vaginal dryness and atrophic vaginitis, urinary disorders (8). Night sweats are the most common menopausal symptoms (9). Hence, it can cause sleep disorders which in turn, may result as insomnia (10). Physical problems may be associated with psychological problems, such as, anxiety, depression and cognitive dysfunction (11). Emotional functioning may differ during menopause which can also vary according to hormonal changes in the body (12). An association between low levels of estrogen and mood disorders has suggested that menopausal women may suffer from mood disorders (13). Especially, premenopausal women have been considered at higher risk of developing depression, anxiety, reduced self-esteem and reduced life enjoyment (14). Due to menopause, loss of fertility may be symbolized as loss of youth and this can cause sadness, which is expressed differently among women (15). Many women during the premenopausal period have indicated increased anxiety and irritability, worry, panic attacks and concentration difficulties (16).

Moreover, women can experience sexual difficulties during menopause depending on their physical, psychological and social status $(17,18)$. Some of the sexual problems experienced during menopause have been identified as decreased frequency of sex, a lack of interest in sex, painful intercourse or feeling compelled to have sex (19). These have been associated with decreased estrogen and ovarian function (17) as well as increased vaginal dryness, which in turn, may influence sexual satisfaction negatively (20).

The purpose of this study was to analyze an association between psychological factors and sexual life experiences in postmenopausal Turkish women. Menopause is one of the most important periods for women, since it may bring significant outcomes. The findings of the current research are expected to enlighten the menopause-related experiences. Describing these experiences may help health professionals who work with postmenopausal women to adopt useful treatment approaches. This study hypothesizes that a) postmenopausal women are less likely to have sexual satisfaction than nonmenopausal women, b) postmenopausal women are more likely to show psychological symptoms than non-menopausal women, and c) postmenopausal women are less likely to experience sexual intercourse than non-menopausal women.

\section{METHOD}

This study was conducted in Antalya, Turkey, between March and July 2016. It included 100 Turkish female participants (50 postmenopausal and 50 non-menopausal females). The participants' age varied between 36-65 years. Participation of the study was voluntary and the participants were included through snowball sampling method. The participation started in a primary health care center, and then more voluntary participants were found through the participants' friends. Informed consent form was completed by the participants before the study. The survey included 5 questionnaires namely, Socio-demographic Information Form, the Menopause Rating Scale (MRS), the Symptom Check List (SCL-R 90), the Arizona Sexual Experience Scale (ASEX) and the Golombok-Rust Inventory of Sexual Satisfaction (GRISS). Participants completed the questionnaires approximately in 15 minutes. 


\section{Instruments}

Socio-demographic form: The form included questions regarding age, gender, education level, history of psychological, physiological treatment, and psychological complaints and drug use.

Menopause Rating Scale (MRS): Menopause Rating Scale (MRS) was used to assess menopausal symptoms in female participants. MRS was developed by Schneider and colleagues (21). This scale includes 11 items which generate three subscales: (a) somatic-hot flushes, heart discomfort/palpitation, sleeping problems and muscle and joint problems; (b) psychological-depressive mood, irritability, anxiety and physical and mental exhaustion and (c) urogenital-sexual problems, bladder problems and dryness of the vagina. Score for each item ranges from "0" (no complaints) to "4" (very severe symptoms) (22). Menopause Rating Scale was translated and adapted to Turkish by Gürkan and it shows good level of internal consistency $(\alpha=0.84)$ (22).

Symptom Check List (SCL-R 90): SCL-90 scale was developed by Derogatis in 1977 [23]. Validity and reliability study of the Turkish version of this scale (SCL-R 90) was conducted by Dağ and it is frequently used in examination of psychopathology (23). It demonstrates very good level of internal consistency $(?=0.97)$. The SCL-R 90 consists of 90 items, each rated on a 5-point scale. These items generate nine dimensions, namely, somatization, obsessive-compulsive reflects, interpersonal sensitivity, anxiety, hostility, phobic anxiety reflects, paranoid thoughts, psychoticism, and acute symptomatology (24).

Golombok -Rust Inventory of Sexual Satisfaction (GRISS): Golombok-Rust Inventory of Sexual Satisfaction which was developed by Rust and Golombok includes 28 items (25). The aim of this scale is to measure the quality of sexual relationship and the presence and severity of both male and female sexual problems. There are two separate forms for female and male participants. Five dimensions of the inventory are common for both sexes. Female version has two additional dimensions (i.e., vaginusmus and anorgasmia), also male version of the inventory has two additional dimensions (i.e., premature ejaculation and impotence). Each item is rated on a 5 point likert type scale and answers vary between "never" to "always". Higher scores indicate higher level of sexual dysfunction and lower level of sexual quality. Original scale was translated and adapted to Turkish by Tuğrul and colleagues (26) which shows good reliability $(\alpha=$ $0.91, \mathrm{p}<.001)$.

Arizona Sexual Experiences Scale (ASEX): This tool was developed by McGahuey and colleagues (27). It aims to detect sexual difficulties in men and women with depression. It assesses 5 major domains of sexual difficulties namely, sex desire, arousal, vaginal lubrication/penile erection, ability to reach orgasm, and satisfaction with orgasm. The scale has different versions for females and males. Scores range from 1 to 6 (e.g., $1=$ extremely easily; $6=$ never). Higher scores reflect poorer sexual functioning (possible range is 5 to 30 ) (28). Validity and reliability study of Turkish version of the scale demonstrated strong test-retest reliability (baseline: $\alpha=0.89, p<.01 ; 6$ months: $\alpha=0.90)(28)$.

\section{Statistical Analysis}

All the analyses were performed by using a computer program for the multivariate statistics; Statistics Package for the Social Sciences (SPSS), version 20 for Windows. Chi-Square statistical tests were conducted to compare socio-demographic characteristics of postmenopausal and nonmenopausal participants. In addition, Independent Sample t-test was used to analyze the mean scores differences between scales and subscales of MRS, SCL-R 90, GRISS and ASEX in postmenopausal and non-menopausal participants. Moreover, Independent $\mathrm{t}$-test was used to examine whether participants who experienced natural and surgical menopause differ in terms of MRS scores. Finally, Pearson correlation analyses were conducted to see whether psychological symptoms are correlated with menopausal symptoms.

\section{RESULTS}

Participants' age ranged from 36 to 65 years. In the present study, no significant differences were found 
between postmenopausal and non-menopausal participants in terms of socio-demographic characteristics; these include age, educational level, psychological complaints, receiving psychological treatment (psychotherapy/medication or combined treatment) and physiological treatment (Table 1).

In respect with MRS, postmenopausal participants had higher mean scores of somatization and urogenital complaints than non-menopausal participants (Table 2).

Participants who experienced natural and surgical menopause showed several significant differences. Those who had natural menopause had higher somatization mean scores of MRS. Also, they reported greater psychological and urogenital complaints than those who experienced surgical menopause (Table 3).

No significant differences were found between postmenopausal and non-menopausal participants in terms of sex drive, sexual arousal, vaginal mois- ture, orgasm, orgasm satisfying, frequency of sexual intercourse and sexual satisfaction mean scores (Table 4). On the other hand, non-menopausal participants had higher mean scores of communication and sensation related to sexual activity than postmenopausal participants. Nevertheless, postmenopausal participants were more avoidant from sexual activity than non-menopausal participants. Also, postmenopausal participants reported significantly higher vaginismus and anorgasmia mean scores than non-menopausal participants (Table 4).

As a part of sociodemographic questions, participants were asked whether they have psychological complaints, however, postmenopausal and nonmenopausal participants did not differ significantly in terms of having psychological complaints. On the other hand, results of SCL-R 90 indicated that postmenopausal participants had higher mean scores than non-menopausal participants in all dimensions (Table 5).

Correlation analyses showed that menopausal

Table 1. Comparisons of sociodemographic variables between postmenopausal and non - menopausal women

\begin{tabular}{|c|c|c|c|c|c|c|c|c|}
\hline & \multicolumn{2}{|c|}{ Post-menopausal } & \multicolumn{2}{|c|}{ Non-menopausal } & \multicolumn{2}{|c|}{ Total } & \multirow[b]{2}{*}{$\mathbf{x}^{2}$} & \multirow[b]{2}{*}{$p$} \\
\hline & $\mathbf{N}$ & $\%$ & $\mathbf{n}$ & $\%$ & $\mathbf{N}$ & $\%$ & & \\
\hline Age & & & & & & & 3.048 & 0.063 \\
\hline $36-45$ & 11 & 36.7 & 19 & 63.3 & 50 & 50 & & \\
\hline $46-65$ & 39 & 55.7 & 31 & 44.3 & 50 & 50 & & \\
\hline $\begin{array}{l}\text { Participant s } \\
\text { education level }\end{array}$ & & & & & & & 6.330 & 0.176 \\
\hline Primary school & 11 & 73.3 & 4 & 26.7 & 15 & 100 & & \\
\hline Middle school & 5 & 41.7 & 7 & 58.3 & 12 & 100 & & \\
\hline University & 11 & 39.3 & 17 & 60.7 & 28 & 100 & & \\
\hline $\begin{array}{c}\text { Master and } \\
\text { doctorate }\end{array}$ & 3 & 33.3 & 6 & 66.7 & 9 & 100 & & \\
\hline $\begin{array}{l}\text { Having } \\
\text { psychological } \\
\text { treatment }\end{array}$ & & & & & & & 3.030 & 0.082 \\
\hline Yes & 10 & 25.9 & 4 & 10.0 & 17 & 20.2 & & \\
\hline No & 40 & 74.1 & 46 & 90.0 & 67 & 79.8 & & \\
\hline $\begin{array}{l}\text { Having } \\
\text { physiological } \\
\text { treatment }\end{array}$ & & & & & & & 0.211 & 0.500 \\
\hline Yes & 3 & 60.0 & 2 & 40.0 & 5 & 100.0 & & \\
\hline No & 47 & 49.5 & 48 & 50.5 & 95 & 100.0 & & \\
\hline $\begin{array}{l}\text { Having } \\
\text { psychological } \\
\text { complaints }\end{array}$ & & & & & & & 4.167 & 0.059 \\
\hline Yes & 4 & 100.0 & 0 & 0 & 4 & 100.0 & & \\
\hline No & 46 & 47.9 & 50 & 52.1 & 96 & 100.0 & & \\
\hline
\end{tabular}

${ }^{*} \mathrm{p}<0.05$ significant 
Table 2. Comparisons of subscales of MRS mean scores of postmenopausal and non -menopausal women

\begin{tabular}{lcccc}
\hline & Post-menopausal & Non-menopausal & & \\
\cline { 1 - 3 } & $\mathbf{n}=\mathbf{5 0}$ & $\mathbf{n}=\mathbf{5 0}$ & & T \\
\hline Mean \pm SD & Mean \pm SD & 6.894 & $0.000^{*}$ \\
\hline $\begin{array}{l}\text { Somatization } \\
\text { Psychological }\end{array}$ & $9.56 \pm 3.79$ & $5.31 \pm 2.14$ & 5.687 & $0.000^{*}$ \\
\hline $\begin{array}{l}\text { Urogenitaints } \\
\text { complaints }\end{array}$ & $8.92 \pm 3.41$ & $5.52 \pm 2.48$ & & $0.000^{*}$ \\
\hline${ }^{*}<0.05$ significant & $5.80 \pm 2.51$ & $2.94 \pm 1.19$ & 7.257 & \\
\hline
\end{tabular}

symptoms were positively correlated with sexual dysfunction, MRS subscales and SCL-R 90 subscales (Table 6).

\section{DISCUSSION}

The current study aimed to examine psychological factors and sexual life experiences of postmenopausal Turkish women. The findings generally showed that postmenopausal Turkish women may have lower mental health and negative sexuality-related experiences when compared with nonmenopausal Turkish women. Also, menopausal symptoms have been found to be positively associated with psychopathological symptoms yet they have been negatively related with sexual dysfunction in postmenopausal Turkish women. Previous findings have shown that there are many social, biological and psychological factors contributing general well-being of postmenopausal women $(29,30,31)$. Menopause has negatively influenced the quality of life in women $(29,30)$. Particularly, postmenopausal women have been shown to have a tendency to develop anxiety and depression as well as difficulties related to sexual satisfaction (31).

The current findings showed that postmenopausal women were more likely to avoid sexual activity than non-menopausal women. Interestingly, postmenopausal and non-menopausal women did not differ in terms of sex drive, sexual arousal, orgasm, frequency of sexual intercourse and sexual satisfaction. These findings raised an assumption sugges- ting postmenopausal women may tend to report sexual satisfaction although they experienced difficulties during sexual intercourse. The current results are also consistent with those of Dennerstein (14) who indicated that $71 \%$ of the postmenopausal women in European countries continue to have an active sex life although $34 \%$ of them had lesser sexual desire. Loss of fertility associated with menopause can be very difficult to overcome for women (15). A qualitative study analyzing menopausal experiences of Turkish women indicated that postmenopausal women mostly identified menopause as a natural transition period which is unavoidable, yet they tended to associate it with negative concepts such as, fear of getting old and loss of sexual interest (32). Menopausal women generally may try to prove that they did not lose their femininity by reporting that they were still sexually satisfied although sexual intercourse was painful for them. In contrast of current findings, reduced sexual desire and functioning are common symptoms of menopause $(31,33)$. Because of physiological consequences of menopause, excitability and capacity for orgasm decrease, and these have been associated with vaginal dryness, less sexual activity and libido in postmenopausal women $(33,34,35)$. Reduced natural vaginal secretions may result as difficulty in the vaginal flexibility, and this can create pain and discomfort during sexual intercourse $(36,37)$.

This study generally shows that postmenopausal women may have poorer psychological well-being

Table 3. Comparisons of subscales of MRS mean scores of participants who experienced natura 1 and surgical menopause

\begin{tabular}{lcccc}
\hline \multicolumn{1}{c}{ Menopause } & Natural & Surgical & & \\
\hline & $\mathbf{n = 3 2}$ & $\mathbf{n}=\mathbf{1 8}$ & $\mathbf{t}$ & $\boldsymbol{p}$ \\
\hline Somatization & Mean \pm SD & Mean \pm SD & 3.058 & $0.003^{*}$ \\
\hline Psychological complaints & $9.03 \pm 4.04$ & $6.68 \pm 3.36$ & 2.781 & $0.007^{*}$ \\
\hline Urogenital complaints & $8.57 \pm 3.59$ & $6.59 \pm 3.18$ & 3.606 & $0.000^{*}$ \\
\hline$*$ p $<0.05$ significant & $5.58 \pm 2.63$ & $3.80 \pm 2.12$ &
\end{tabular}


Akman S, Çakıcı M, Keskindağ B, Karaaziz M.

Table 4. Comparisons of ASEX and GRISS mean scores of postmenopausal and non -menopausal women

\begin{tabular}{|c|c|c|c|c|}
\hline & Post-menopausal & Non-menopausal & & \\
\hline & $\mathbf{n}=\mathbf{5 0}$ & $\mathbf{n}=\mathbf{5 0}$ & & \\
\hline & Mean \pm SD & Mean \pm SD & $\mathbf{t}$ & $p$ \\
\hline \multicolumn{5}{|l|}{ ASEX } \\
\hline Sex drive & $3.72 \pm 1.37$ & $2.54 \pm 1.36$ & 4.32 & 0.920 \\
\hline Sexually aroused & $3.42 \pm 1.22$ & $2.50 \pm 1.30$ & 3.73 & 0.561 \\
\hline Vaginal moisture & $3.54 \pm 1.23$ & $2.20 \pm 1.20$ & 5.51 & 0.701 \\
\hline Orgasm & $3.64 \pm 1.57$ & $2.56 \pm 1.25$ & 4.48 & 0.480 \\
\hline Orgasm satisfy & $3.16 \pm 1.28$ & $2.14 \pm 1.03$ & 4.48 & 0.100 \\
\hline \multicolumn{5}{|l|}{ GRISS } \\
\hline Sexual intercourse & $4.40 \pm 1.16$ & $4.49 \pm 0.88$ & -0.433 & 0.661 \\
\hline $\begin{array}{l}\text { Communication satisfaction on } \\
\text { sexual activity }\end{array}$ & $4.47 \pm 1.73$ & $5.22 \pm 1.83$ & -2.099 & $0.038^{*}$ \\
\hline Sexual satisfaction & $10.59 \pm 2.25$ & $10.97 \pm 1.73$ & -0.944 & 0.350 \\
\hline Avoidance from sexual activity & $7.21 \pm 3.02$ & $5.05 \pm 2.27$ & 4.037 & $0.000^{*}$ \\
\hline Sensation on sexual activity & $10.02 \pm 2.20$ & $11.36 \pm 1.89$ & 2.809 & $0.010^{*}$ \\
\hline Vaginusmus & $10.93 \pm 6.86$ & $8.20 \pm 2.34$ & 2.667 & $0.010 *$ \\
\hline Anorgasmia & $10.68 \pm 1.54$ & $9.30 \pm 2.03$ & 3.821 & $0.000 *$ \\
\hline
\end{tabular}

$* \mathrm{p}<0.05$ significant

than those who are not in menopausal period $(14,15)$. During the menopausal period, hormones can influence on psychological symptoms which may trigger somatization, depression and anxiety (33). Considering that regular menstruation shows fertility and femininity, menopause may represent the loss of the femininity (38). Beliefs and traditional values reflect culture and ethnicity. Regarding menopause, some cultures tend to consider loss of regular bleeding negatively since it refers to "an end of fertility and the end of youth" (39). Similarly, a study conducted among 1551 Turkish women investigating menopause attitudes and status showed that $90.7 \%$ of the women considered menopause as "the end of youth", $85.8 \%$ viewed it as "the beginning of getting older", and $97.6 \%$ evaluated it as "the end of fecundity" (40). Hunter (41) has reported that social values can be important factor for psychiatric symptoms. For instance, negative attitudes towards older women who cope with menopause affect their self-esteem and self-confidence negatively (12). Culture related negative attitudes may contribute depression in postmenopausal women. Schmidt and colleagues (1) have demonstrated that postmenopausal women can experience depression, anxiety, fatigue, forgetfulness and reduced self-confidence. They also experience various emotional problems including mood swings and anger and these problems are difficult to cope with (30). In parallel with previous evidence, the current study found that postmenopausal women had higher levels of anger, hostility and anxiety symptoms than nonmenopausal women. Cultural beliefs, psychological and physical symptoms in menopause may interact and they together may influence postmenopausal

Table 5. Comparisons of subscales of SCL -R 90 mean scores of postmenopausal an d non-menopausal women

\begin{tabular}{|c|c|c|c|c|}
\hline & $\begin{array}{c}\text { Postmenopausal } \\
\text { women }\end{array}$ & $\begin{array}{c}\text { Non-menopausal } \\
\text { women }\end{array}$ & & \\
\hline & $\mathrm{n}=\mathbf{5 0}$ & $\mathrm{n}=\mathbf{5 0}$ & & \\
\hline & Mean \pm SD & Mean \pm SD & $t$ & $P$ \\
\hline Somatization & $26.15 \pm 8.12$ & $18.23 \pm 6.73$ & 5.308 & $0.000^{*}$ \\
\hline $\begin{array}{l}\text { Obssessive } \\
\text { compulsive }\end{array}$ & $19.40 \pm 6.26$ & $15.08 \pm 5.44$ & 3.681 & $0.000^{*}$ \\
\hline $\begin{array}{l}\text { Interpersonal } \\
\text { sensitivity }\end{array}$ & $16.35 \pm 6.29$ & $12.60 \pm 5.17$ & 3.255 & $0.002 *$ \\
\hline Depression & $27.17 \pm 9.46$ & $19.34 \pm 7.46$ & 4.593 & $0.000^{*}$ \\
\hline Anxiety & $17.96 \pm 7.12$ & $12.47 \pm 4.35$ & 4.648 & $0.000^{*}$ \\
\hline Anger-hostility & $9.75 \pm 4.05$ & $7.82 \pm 3.36$ & 2.594 & $0.011 *$ \\
\hline Psychoticism & $14.82 \pm 5.43$ & $11.51 \pm 3.70$ & 3.554 & $0.001 *$ \\
\hline Phobia & $9.89 \pm 4.72$ & $7.46 \pm 2.02$ & 3.344 & $0.001 *$ \\
\hline Paranoid thoughts & $10.31 \pm 4.30$ & $8.48 \pm 3.12$ & 2.424 & $0.017 *$ \\
\hline
\end{tabular}


Table 6. Correlation between subscales of sexual satisfaction, MRS, SCL -R 90 scores and menopausal symptoms

\begin{tabular}{lcc}
\hline & \multicolumn{2}{c}{ Menopausal Symptoms } \\
\hline Sexual satisfaction & $\mathrm{r}$ & $p$ \\
Satisfaction & 0.158 & 0.117 \\
\hline Communication & -0.214 & $0.032^{*}$ \\
\hline Frequency & 0.194 & 0.053 \\
\hline Avoidance & 0.400 & $0.000^{*}$ \\
\hline Sensation & -0.259 & $0.009^{*}$ \\
\hline Vaginismus & 0.264 & $0.008^{*}$ \\
\hline Anorganisma & 0.343 & $0.000^{*}$ \\
\hline MRS & & \\
Somatization & 0.593 & $0.000^{*}$ \\
\hline Psychological complaints & 0.517 & $0.000^{*}$ \\
\hline Urogenital complaints & 0.604 & $0.000^{*}$ \\
\hline SCL-R 90 & & \\
\hline Somatization & 0.480 & $0.000^{*}$ \\
\hline Obsessive-compulsive & 0.347 & $0.000^{*}$ \\
\hline Interpersonal relations & 0.311 & $0.000^{*}$ \\
\hline Depression & 0.421 & $0.000^{*}$ \\
\hline Anxiety & 0.416 & $0.000^{*}$ \\
\hline Hostility & 0.246 & $0.000^{*}$ \\
\hline Phobia & 0.326 & $0.001^{*}$ \\
\hline Paranoid thoughts & 0.241 & $0.016^{*}$ \\
\hline Psychotism & 0.344 & $0.000^{*}$ \\
\hline *p $<0.05$ significant & & \\
\hline
\end{tabular}

women's mental health.

Earlier study has stated that women who experience surgical menopause tend to show less menopausal symptoms (31). In case of experiencing surgical menopause at early age, menopausal symptoms may not be clear even. On the other hand, women who experience natural menopause usually show menopausal symptoms because of active change in hormones and its effects on the body. Natural menopause stems from follicular atresia in where the ovaries lose their functionality, ovulation stops, and reproduction of the woman ends. In this state, the estrogen levels are at lowest level (42). However, surgical menopause occurs suddenly (5). Consistently, the current findings showed that those women who experienced natural menopause had greater menopausal symptoms than those who experienced surgical menopause. Considering that the natural and surgical menopausal processes show physical differences, it is not surprising that women who experienced natural menopause had more intense menopausal symptoms in this study.

It should be noted that this study has several limitations. The cross-sectional design does not allow drawing causal relationships. Also, snowball sampling and the number of participants who experienced surgical menopause can be considered as limitations of this study which may influence the interpretations of the results. Furthermore, participants have not been investigated in terms of period of time since menopause started and whether they have a sexual partner. Besides, it is known that GRISS examines sexual satisfaction of heterosexual women; hence it may not represent women who have different sexual orientation. Although this study has some limitations, it draws attention to an inconsistency of experiences and expressions among Turkish postmenopausal women. The findings of this study are important in informing health care services for postmenopausal women.

\section{CONCLUSION}

The findings of the current study are consistent with previous evidence suggesting that postmenopausal women may have poorer psychological well-being than non-menopausal women. Healthcare professionals should be aware that postmenopausal women should be considered as biologically, psychologically as well as socially. Furthermore, sexuality related experiences are 
important aspects of physical and emotional health for postmenopausal women. However, it is interesting that postmenopausal women in the current study did not report lower sexual satisfaction although they tended to avoid from sexual activity. Since menopause may represent loss of fertility, this may be difficult for a woman in many aspects (i.e. psychological, physical and biological). Specifically, postmenopausal women may try to overcome psychological difficulties by indicating that they still have sexual satisfaction which may represent femininity. Further research should comprehensively assess how postmenopausal women

\section{REFERENCES}

1. Schmidt PJ, Ben Dor R, Martinez PE, Guerrieri GM, Harsh V, Thompson K, Koziol DE, Nieman LK, Rubinow DR.. Effects of estradiol withdrawal on mood in women with past perimenopausal depression: a randomized clinical trial. JAMA Psychiatry, 2015;72: 714-26.

2. Gharaibeh M, Al-Obeisat S, Hattab J. Severity of menopausal symptoms of Jordanian women. Climacteric 2010;13: 385-394.

3. Okeke TC, Anyaehie UB, Ezenyeaku CC. Premature Menopause. Ann Med Health Sci Res. 2013;3: 90-96.

4. Schneider HP, Heinemann LA, Rosemeier HP, Potthoff $P$, Behre HM. The Menopause Rating Scale (MRS): reliability of scores of menopausal complaints. Climacteric 2000;3:59-64.

5. Morrie M, Gelfand MD. Role of androgens in surgical menopause. Obstetric and Gynecology 1999;180:325-328.

6. Binfa L, Castelo-Branco C, Blümel JE, Cancelo MJ, Bonilla H, Muñoz I, Vergara V, Izagurre H, Sarrá S, Ríos RV. Influence of psycho-social factors on climacteric symptoms. Maturitas 2014; 48:425-31

7. Studd JWW, Whitehead MI. The Menopause. Edinburgh: Blackwell Scientifıc Publications, 1988.

8. Donald M, Fries D. Take Care Of Yourself. Newyork, N.Y., Addison-Wasley Publishing Company; 1996.

9. Speroff L. Postmenopausal hormone therapy and breast cancer. Obstetrics \& Gynecology 1996;87: 44S-54S.

10. Hatcher H. Sleep in post-menopausal women: differences between early and late post-menopause. Obstet Gynecol Reprod Biol. 1996: 1-4.

11. Pattern L. International health report: menopause in various cultures: A portrait of the menopause. Carnforth, Parthenon, 1992.

12. Aaron R, Muliyil J, Abraham S. Medico-social dimensions of menopause: a cross-sectional study from rural south India. Natl Med J India 2002;15:14-7.

13. Igarashi M. Stress vulnerability and climacteric symptoms: life events, coping behavior, and severity of symptoms. Gynecol Obstet Invest 2000;49:100-170

14. Dennerstein L. Well-being, symptoms and the menopausal transition. Maturitas 1996;23:147-157. perceive menopause and related psychological symptoms. In the light of future studies, health care professionals may better understand psychological and physical experiences of postmenopausal women.

Correspondence address: Assis. Prof. Meryem Karaaziz, Department of Psychology, Near East University, Nicosia, TRNC meryem.karaaziz@neu.edu.tr

15. Aydın H. Cinsellik ve Cinsel İşlev. Temel Psikiyatri, Cilt 2. Edited by Güleç C., Köroğlu E. Ankara, HYB Yayıncılık, 1998.

16. Stewart DE, Boydell K, Derzko C, Marshall V. Psychologic distress during the menopausal years in women attending a menopause clinic. Int J Psychiatry Med 1992;22:213-220.

17. Masters WH, Johnson VE. Human Sexual Response. Boston, Little Brown \& Company, 1994.

18. Greendale A. Change in sexual functioning over the menopausal transition: results from the Study of Women's Health Across the Nation. Journal of The Nation Menopause Society 1994;10:10-22.

19. Hunter M, Rendall M. Bio-psycho-socio-cultural perspectives on menopause. Best Pract Res Clin Obstet Gynaecol 2007; 21: $261-74$

20. Philips NA. FemaleSexual Dysfunction: Evaluation and Treatment. New Zealand, University of Otego Wellington, 2000.

21. Schneider HP, Heinemann LA, Rosemeier HP, Potthoff P, Behre HM. The Menopause Rating Scale (MRS): reliability of scores of menopausal complaints. Climacteric, 2000;3: 59-64.

22. Gürkan C. Menopoz semptomları değerlendirme ölçeğinin Türkçe formunun güvenirlik ve geçerliliği. Hemşirelik Forumu Dergisi 2005: 30-35. Turkish.

23. Dağ İ. Belirti Tarama Listesi (SCL-90-R)'nin üniversite öğrencileri için güvenirliği ve geçerliği. Türk Psikiyatri Dergisi 1991; 2: 5-12. Turkish.

24. Derogatis LR. Symptom Checklist 90-R: Administration, Scoring, and Procedures Manual (3rd ed.). Minneapolis, MN, National Computer Systems, 1994.

25. Rust J, Golombok S. The Golombok-Rust Inventory of Sexual Satisfaction (GRISS). Br J Clin Psychol 1985; 24: 63-64.

26. Tuğrul C, Öztan N, Kabakçı E. Golombok-Rust cinsel doyum ölçeği'nin standardizasyon çalışması. Türk Psikiyatri Dergisi 1993; 4:83-88. Turkish.

27. McGahuey CA, Gelenberg AJ, Laukes CA, Moreno FA, Delgado PL, McKnight KM Manber R. The Arizona Sexual Experience Scale (ASEX): reliability and validity. J Sex Marital Ther 2000; 26:25-40.

28. Soykan A. The reliability and validity of Arizona sexual 
experiences scale in Turkish ESRD patients undergoing hemodialysis. Int J Impot Res. 2004; 16(6):531-4.

29. Roberts H. Managing the menopause. BMJ 2007; 334(7596):736-741.

30. Taylor HS. Hot flashes: avoiding the reductionist view. Menopause 2016;23: 1053-4.

31. Varma G, Oğuzhanoğlu N, Karadağ F. The Relationship Between Depression and Anxiety Levels and Sexual Satisfaction for Natural and Surgical Menopause. J Clin Psychiatry 2005;8: 109-115.

32. Cifcili SY, Akman M, Demirkol A, Unalan PC, Vermeire E "I should live and finish it": A qualitative inquiry into Turkish women's menopause experience. BMC Fam Pract. 2009; 10:2.

33. Dennerstein L, Randolph J, Taffe J, Dudley E, Burger H Hormones, mood, sexuality, and the menopausal transition. Fertil Steril 2002; 77:42-48.

34. Goldstein RB, Bree RL, Benson CB, Benacerraf BR, Bloss JD, Carlos R, Fleischer AC, Goldstein SR, Hunt RB, Kurman RJ, Kurtz AB, Laing FC, Parsons AK, Smith-Bindman R, Walker J. Evaluation of the woman with postmenopausal bleeding: Society of Radiologists in Ultrasound-Sponsored Consensus Conference statement. J Ultrasound Med 2001; 20:1025-36.

35. Brazier JE, Roberts J, Platts M, Zoellner YF. Estimating a preference-based index for a menopause specific health quality of life questionnaire. Health Qual Life Outcomes 2005; 3:13.

36. Chalker R. The National Women's Health Network: Menopause Sexuality, 2009.2009 https: //www.nwhn.org/wp-content/uploads/2015/08/Menopauseand-Sexuality.pdf Erisim tari- hi: Agustos 17, 2017.

37. Cawood EH, Bancroft J. Steroid hormones, the menopause, sexuality and well-being of women. Psychol Med 1996; 26:92536.

38. Rahman S, Salehin F, Iqbal A. Menopausal symptoms assessment among middle age women in Kushtia, Bangladesh. BMC Res Notes 2011; 4:188

39. Castelo-Branco C, Palacios S, Mostajo D, Tobar C, von Helde S. Menopausal transition in Movima women, a Bolivian Native-American. Maturitas 2005;51:380-5.

40. Ayranci U, Orsal O, Orsal O, Arslan G, Emeksiz DF. Menopause status and attitudes in a Turkish midlife female population: an epidemiological study. BMC Women's Health 2010; 10:1-14.

41. Hunter M. Depression and the menopause (editorial). BMJ 1996;313:1217-1218.

42. Salvador J. Climacteric and menopause: epidemiology and pathophysiology. Ginecol Obstet 2008;5:61-78. 